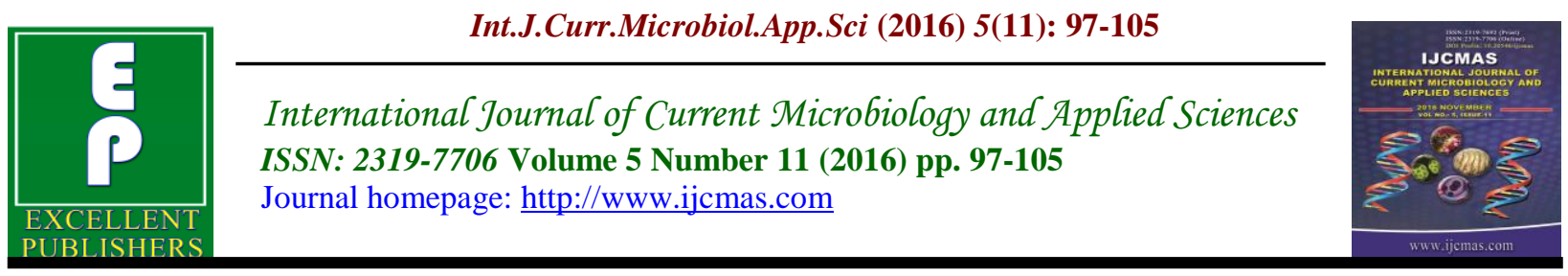

Original Research Article

http://dx.doi.org/10.20546/ijcmas.2016.511.011

\title{
Effects of Carbon Sources and Time of Cultivation on the Antimicrobial Activities of Intra and Extracellular Extracts of Pleurotus pulmonarius Cultured in Submerged Conditions
}

\author{
Bruna Polacchine da Silva*, Josielle Abrahão and Rosane Marina Peralta \\ Department of Biochemistry, Universidade Estadual de Maringá, Brazil \\ *Corresponding author
}

\section{A B S T R A C T}

\section{Keywords}

Pleurotus

pulmonarius, medicinal mushroom, oyster mushroom, antimicrobial activity, antifungal activity.

\section{Article Info}

Accepted:

04 October 2016

Available Online:

10 November 2016
Pleurotus spp are edible mushrooms that have also high nutritional and medicinal value. The aim of the present study was to evaluate the antimicrobial activities of Pleurotus pulmonarius intra- and extracellular extracts, obtained in submerged cultures using different carbon sources (glucose, cassava starch and cassava bagasse) and cultivation times of up to 8 days. The antimicrobial activities were characterized by evaluating the zone of inhibition, the minimal inhibitory concentration and the bactericidal concentration (MIC and MBC, respectively). The results showed that highest antimicrobial activities were found in 6 day mycelial extracts obtained in cultures using glucose and starch as carbon source. These extracts presented considerable antimicrobial activity against Escherichia coli, Salmonella enterica, Staphylococcus aureus, Bacillus subtilis and Bacillus cereus. The same extracts were also able to inhibit growth of Candida albicans. These results shows that the mycelial extracts of $P$. pulmonarius are promising natural source of antimicrobial agents.

\section{Introduction}

Pleurotus spp.are famous for owning all three properties expected from a food, nutrition, taste, and physiological functions, being thus appreciated for both their sensory characteristics and outstanding nutritional profile (Corrêa et al., 2016). Both basidiomata and mycelium of mushrooms contain different groups of compounds such as terpenoids, lactones, organic acids, steroids, polyphenols, tocopherols, flavonoids, phenolics, alkaloids, polysaccharides and dietary fibers. These compounds possess antioxidant, antineoplastic, antitumor, immunomodulatory and anti-inflammatory activities and are responsible by the functional and medicinal properties of Pleurotus spp. (Corrêa et al., 2016).

Furthermore, an antimicrobial activity was also reported for both the basidioma and the mycelium of various species of the genus such as $P$. nebrodensis and $P$. eryngii (Schillacietal, 2013), P. djamor (Dharmaraj et al., 2014) P. ostreatus (Younis et al., 2015), P. ostreatoroseus (Corrêa et al., 2015) and $P$. pulmonarius (Adebayo et al., 2012). 
The production of basidiomata by Pleurotus spp. may take months. An alternative for obtaining bioactive compounds in shorter periods could be to explore the mycelial biomass obtained from submerged cultures (Ragunathan and Swaminathan, 2003; Elisashvili, 2012). The aim of the present study was to evaluate the antimicrobial activities of Pleurotus pulmonarius intraand extracellular extracts, obtainedby submerged cultures using different carbon sources (glucose, cassava starch and cassava bagasse) cultivation times of up to 8 days. Cassava bagasses an abundant and easy to obtain agricultural residue, reducing the costs for culturing $P$. pulmonarius.

\section{Materials and Methods}

\section{Experimental}

Cultivation of $\boldsymbol{P}$. pulmonarius in submerged conditions and obtainment of intra- and extracellular extracts

P. pulmonarius CCB 19 was obtained from the Culture Collection of the Botany Institute of São Paulo, Brazil. It was cultured on potato dextrose agar (PDA) medium for 1 week at $28^{\circ} \mathrm{C}$. Stock cultures were maintained on agar-potato-dextrose plates (PDA) and stored at $4{ }^{\circ} \mathrm{C}$ for up to 2 months. The cassava bagasse was dried on oven at $40{ }^{\circ} \mathrm{C}$ under air circulating and subsequently milled in a knife mill. Three mycelia discs $(\varnothing 10 \mathrm{~mm})$ were inoculated in $150 \mathrm{~mL}$ of liquid medium containing potato extract $(200 \mathrm{~g} / \mathrm{L})$, glucose $(15 \mathrm{~g} / \mathrm{L})$ and Vogel mineral solution (Vogel, 1956) and maintained under agitation of $120 \mathrm{rpm}$ at $28^{\circ}$ C. After 5 days, around $5.7 \mathrm{~g}$ of the moist mycelium ( $\pm 0.254 \mathrm{~g}$ mycelia dry weight) were transferred to a $1000 \mathrm{~mL}$ Erlenmeyer flask containing $300 \mathrm{~mL}$ of a medium consisting in $3.4 \%$ carbon source (cassava bagasse, cassava starch or glucose), $0.2 \%$ of $\mathrm{NH}_{4} \mathrm{NO}_{3}$ and Vogel salts without nitrogen source. The cultures were maintained for up to 8 days at $28^{\circ} \mathrm{C}$ under agitation of 120 rpm. Fungal biomass and extracellular material were separated by centrifugation at $5000 \mathrm{rpm}$ for $10 \mathrm{~min}$ at $4{ }^{\circ} \mathrm{C}$. The fungal biomass was washed twice with cold distilled water, pressed between sheets of paper and frozen. Equal amounts of frozen fungal biomass, corresponding to both tested carbon sources were macerated with glass beads, centrifuged at $10,000 \mathrm{rpm}$, for $15 \mathrm{~min}$ at $4^{\circ} \mathrm{C}$, and the supernatants were subsequently used as the intracellular extracts. Both intra- and extracellular extracts were lyophilized and stored in a freezer $\left(-20^{\circ} \mathrm{C}\right)$ until use.

\section{Antimicrobial activity}

\section{Determination of antimicrobial activity by the disk diffusion test}

The bacteria were grown in Mueller Hinton Agar (Merck) and Mueller Hinton Broth (Merck) and the yeasts were grown in PDA and Sabauround Broth. The following Gram-negative bacteria were used: Escherichia coli (ATCC 25922), Pseudomonas aeruginosa (ATCC 7966), Salmonella enterica (ATCC 13076), Klebsiela pneumoniae (ATCC 700603), Aeromonas hydrophila (ATCC 7966). The following Gram-positive bacteria were used: Staphylococcus aureus (ATCC 25923), Bacillus subtilis (ATCC 6051), Bacillus cereus (INCQS 00003). Two fungi were used: Candida albicans (ATCC 10231) and Saccharomyces cerevisiae. All microorganisms were obtained from the Microbiology Laboratory of Water, Environment and Food of the State University of Maringá.

The disk diffusion test was performed on Muller-Hinton agar for bacteria and MullerHinton agar medium with $2 \%$ dextrose and $0.5 \mu \mathrm{g} / \mathrm{mL}$ methylene blue for yeasts, as 
recommended by NCCLS M2-A8 and NCCLS M44-A2, respectively. The disks containing extracts of $P$. pulmonarius were produced using $6 \mathrm{~mm}$ filter paper discs containing $10 \mu \mathrm{L}$ of a solution with 100 $\mathrm{mg} / \mathrm{mL}$ extract. With the purpose of standardization, the inoculum samples were collected from three to five colonies of each organism and suspended in $3.0 \mathrm{~mL}$ of a physiological saline solution $(0.85 \%)$. The turbid suspension was then visually compared with the standard 0.5 of the McFarland scale, equivalent to $10^{8} \mathrm{CFU} / \mathrm{mL}$ for bacteria and $10^{6} \mathrm{CFU} / \mathrm{mL}$ for yeasts. Subsequently, the suspensions were sown and the discs placed on the agar. The plates were incubated at $37^{\circ} \mathrm{C}$ for bacteria and $35^{\circ} \mathrm{C}$ for yeasts for 24 hours. After this period the halos were measured. The experiment was performed in duplicate in three independent events. Disks containing gentamicin $(10 \mu \mathrm{g})$ (Laborclin), vancomycin (30 $\mu \mathrm{g})$ (Laborclin), chloramphenicol (30 $\mu \mathrm{g}$ ) (Laborclin), for bacteria and fluconazole $(25 \mu \mathrm{g} / \mathrm{ml})$ for yeasts, were used as controls. The halos were measured after 24 hours of incubation.

\section{Determination of antimicrobial activity by the micro dilution method}

The antimicrobial activity was determined as the minimum inhibitory concentration (MIC), which was determined using the micro dilution methodology as described in the NCCLS M7-A6 with slight modifications. Different concentrations of intra- and extracellular extracts of $P$. pulmonarius CCB19 (final concentrations varying from 0.39 to $100 \mathrm{mg} / \mathrm{mL}$ ) were prepared by serial dilution in broth media specific for each microorganism, Muller Hilton broth (Merck) for bacteria and Sabauround broth for yeasts. With the purpose of standardization samples were collected from three to five colonies of each organism and suspended in $3.0 \mathrm{~mL}$ of a physiological saline solution $(0.85 \%)$. The turbid suspension was then visually compared with the standard 0.5 of the McFarland scale, equivalent to $10^{8} \mathrm{CFU} / \mathrm{mL}$ for bacteria and $10^{6} \mathrm{CFU} / \mathrm{mL}$ for yeasts. In the micro dilution test in 96-well plates, bacteria samples containing $10^{8} \mathrm{CFU} / \mathrm{mL}$ were removed and placed in $0.1 \mathrm{~mL}$ of $0.85 \%$ physiological saline solution. To each well containing $190 \mu \mathrm{L}$ of extract, $10 \mu \mathrm{L}$ of inoculum was added. In the determination of the antimicrobial activity against yeast, inoculum was added to obtain final concentrations ranging from $0.5 \times 10^{3}$ to 2.5 x $10^{3}$ cells $/ \mathrm{mL}$. Negative controls without extracts were conducted in the same way. The antibiotics gentamicin and streptomycin and the antifungal fluconazole were used as positive controls. The 96 well plates were incubated for 24 hours in an oven $37{ }^{\circ} \mathrm{C}$ for bacteria and $35{ }^{\circ} \mathrm{C}$ for yeasts and optical performed in a spectrophotometer at 630 nm. The MIC was corresponded to the lowest concentration of extract that inhibited growth of the microorganism.

The Minimum Bactericidal Concentration (MBC) was determined based on the Santurio methodology (2007), whereas the wells in which no visible bacterial growth was removed from an aliquot of $10 \square \mathrm{L}$ and plated on agar surface Muller Hilton incubated at $37{ }^{\circ} \mathrm{C}$ for 24 hours, the MBC was defined as the lowest concentration of the extract able to cause the death of inoculum.

To determine the Minimum Fungicidal Concentration (MFC), an aliquot of $10 \mu \mathrm{L}$ of each micro plate well was plated on plates containing Sabouraud dextrose agar. After incubation for $48 \mathrm{~h}$ at $37{ }^{\circ} \mathrm{C}$, the $\mathrm{MFC}$ was defined as the lowest concentration of drug capable of causing the death to $100 \%$ of fungal cells. This was demonstrated by the absence of colonies in plate. 


\section{Statistical analysis}

All analyses were performed in triplicate. The data were expressed as means \pm standard deviations. Data were analyzed using GraphPad Prism 6.0 program.

\section{Results and Discussion}

\section{Antimicrobial activity by diffusion test and micro dilution method}

The intra- and extracellular extracts of $P$. pulmonarius were tested against several Gram-positive and Gram-negative bacteria on agar disc diffusion method and the results are presented in Table 1. Extracts producing inhibition zones greater than $10 \mathrm{~mm}$ were considered as highly active. Both intra- and extracellular extracts can be classified as highly active, especially against the Gram negative bacteria $E$. coli and $S$. enteric, and the Gram positive bacteria $S$. aureus, $B$. subtilis and B. cereus.

Considering the results above, the minimal inhibition concentration (MIC) and the minimal bactericidal concentration (MBC) were determined for the five most sensitive bacteria. The results are presented in Table 2. The results show that highest antimicrobial activities are found in $6 \mathrm{~d}$ mycelial extracts obtained in submerged cultures using glucose and starch as carbon sources.

\section{Antifungal test}

Antifungal test of the extracts were performed against Candida albicans (ATCC 10231) and Saccharomyces cerevisiae (Table 3). The extracts were not effective against Saccharomyces cerevisiae but for Candida albicans the best result (disc diffusion) is the 6d-intracellular extract obtained in cultures using starch as substrate. Extracts able to inhibit 50\% of
Candida albicans were the $2 \mathrm{~d}$-extracellular extract obtained using glucose as substrate $(75.0 \mathrm{mg} / \mathrm{mL})$ and the 6d-intracellular extract obtained in cultures using starch as substrate $(75.0 \mathrm{mg} / \mathrm{mL})$. There was no fungicidal effect on the maximum concentration tested.

Infectious diseases are the second cause of death worldwide and the research for active compounds for treatment of these diseases is required (WHO, 2012. new antibacterial drugs are needed and the mushrooms could be a natural source of antibiotics. Among Pleurotus spp., the majority of studies of antimicrobial activity was conducted using both mushroom and mycelia of $P$. ostreatus (Barak and Sadik, 2014; Sala et al., 2015; Vamanu, 2012; Younis et al., 2015). However, the number of investigations on the antimicrobial activity of $P$. pulmonarius is still small (Adebayo et al., 2012). In the present study $100 \mathrm{mg} / \mathrm{disc}$ of an aqueous $6 \mathrm{~d}$ $P$. pulmonarius extract, obtained using different substrates, were effective against the Gram-positive bacteria B. subtilis (26.0 $\pm 1.2 \mathrm{~mm})$, S. aureus $(33.0 \pm 1.4 \mathrm{~mm})$, and $B$. cereus $(8.0 \pm 0 \mathrm{~mm})$ and against the Gramnegative bacteria Salmonella enteric $(22.5 \pm 3.5 \mathrm{~mm})$ and $E$. coli $(16.5 \pm 2.1 \mathrm{~mm})$. For comparative purposes, Sala et al. (2015) evaluated the antimicrobial activity of hexane, chloroform and ethyl acetate extracts of $P$. ostreatus at a concentration of $500 \mathrm{mg} / \mathrm{disc}$ and found that the hexane extract was active against the Gram-positive bacteria $B$. subtilis $(12.80 \pm 0.3 \mathrm{~mm})$ and $S$. aureus $(20.21 \pm 0.7 \mathrm{~mm})$, while on antimicrobial activity was detected against $B$. cereus. In the same work, a $P$. ostreatus chloroform extract was effective against $S$. paratyphi $(16.32 \pm 0.6 \mathrm{~mm})$ and $E$. coli $(17.00 \pm 0.1 \mathrm{~mm})$. These data allow concluding that $P$. pulmonarius extracts can be as effective as $P$. ostreatus extracts as antimicrobial agents. 
Table.1 Preliminary antimicrobial testing of Pleurotus pulmonarius extracts through determination of zone of inhibition (mm \pm SD)*

\begin{tabular}{|c|c|c|c|c|c|c|c|c|c|c|c|}
\hline \multirow{3}{*}{\multicolumn{2}{|c|}{ Extracts }} & \multicolumn{5}{|c|}{ Extracellular extracts } & \multicolumn{5}{|c|}{ Intracellular extracts } \\
\hline & & \multicolumn{2}{|c|}{ Gram-negative } & \multicolumn{3}{|c|}{ Gram-positive } & \multicolumn{2}{|c|}{ Gram-negative } & \multicolumn{3}{|c|}{ Gram-positive } \\
\hline & & $\begin{array}{l}\text { E.coli } \\
25922\end{array}$ & $\begin{array}{c}\text { S. enteric } \\
13076\end{array}$ & $\begin{array}{c}\text { S. aureus } \\
25923\end{array}$ & $\begin{array}{l}\text { B. subtilis } \\
6051\end{array}$ & $\begin{array}{c}\text { B. cereus } \\
00003\end{array}$ & $\begin{array}{l}\text { E.coli } \\
25922\end{array}$ & $\begin{array}{c}S . \\
\text { enteric } \\
13076 \\
\end{array}$ & $\begin{array}{c}\text { S. aureus } \\
25923\end{array}$ & $\begin{array}{l}\text { B. subtilis } \\
6051\end{array}$ & $\begin{array}{c}B . \\
\text { cereus } \\
00003 \\
\end{array}$ \\
\hline \multirow{3}{*}{2 days } & Glucose & -- & $7.0 \pm 1.4$ & $20.5 \pm 0.7$ & $16.0 \pm 1.4$ & - & -- & -- & - & -- & -- \\
\hline & Starch & $7.5 \pm 0.7$ & $16.5 \pm 0.7$ & $26.5 \pm 0.7$ & $26.5 \pm 0.7$ & -- & -- & -- & -- & -- & -- \\
\hline & Bagasse & -- & -- & -- & -- & -- & -- & $16.5 \pm 2.1$ & $28.0 \pm 1.4$ & $20.5 \pm 0.7$ & -- \\
\hline \multirow{3}{*}{4 days } & Glucose & -- & -- & -- & -- & -- & -- & -- & -- & -- & -- \\
\hline & Starch & $10.5 \pm 0.7$ & $16.5 \pm 2.1$ & $24.5 \pm 0.7$ & $22.0 \pm 1.4$ & -- & -- & -- & -- & -- & -- \\
\hline & Bagasse & $11.0 \pm 1.4$ & $18.0 \pm 1.4$ & $26.5 \pm 0.7$ & $25.5 \pm 0.7$ & -- & -- & -- & $10.5 \pm 2.1$ & -- & -- \\
\hline \multirow{3}{*}{6 days } & Glucose & -- & $10.5 \pm 0.7$ & $20.5 \pm 3.5$ & $24.5 \pm 0.7$ & - & $15.5 \pm 0.7$ & $22.5 \pm 0.7$ & $31.0 \pm 1.4$ & $26.0 \pm 4.2$ & $8.0 \pm 0$ \\
\hline & Starch & -- & $9.5 \pm 0.7$ & $25.5 \pm 0.7$ & $22.5 \pm 0.7$ & -- & $16.5 \pm 2.1$ & $22.5 \pm 3.5$ & $33.0 \pm 1.4$ & $17.0 \pm 1.4$ & $7.0 \pm 0$ \\
\hline & Bagasse & -- & $10.0 \pm 1.4$ & $25.5 \pm 0.7$ & $22.0 \pm 1.4$ & -- & -- & $16.5 \pm 2.1$ & $25.5 \pm 0.7$ & $24.0 \pm 0$ & -- \\
\hline \multirow{3}{*}{8 days } & Glucose & -- & -- & -- & -- & -- & $12.0 \pm 1.4$ & $17.0 \pm 1.4$ & $28.5 \pm 2.1$ & $28.5 \pm 0.7$ & -- \\
\hline & Starch & -- & -- & $12.5 \pm 0.7$ & $20.5 \pm 0.7$ & -- & -- & $8.0 \pm 1.4$ & $21.5 \pm 2.1$ & $23.5 \pm 0.7$ & -- \\
\hline & Bagasse & -- & -- & $17.5 \pm 0.7$ & $23.5 \pm 2.1$ & -- & -- & $7.5 \pm 0.7$ & $19.0 \pm 1.4$ & $21.5 \pm 2.1$ & -- \\
\hline \multirow{3}{*}{\multicolumn{2}{|c|}{$\begin{array}{l}\text { Chloramphenicol } \\
\text { Gentamicin } \\
\text { Vancomicin }\end{array}$}} & $33.5 \pm 2.1$ & $32.0 \pm 1.4$ & $29.5 \pm 0.7$ & $32.5 \pm 1.5$ & $20.0 \pm 0.5$ & & & & & \\
\hline & & $25.0 \pm 0$ & $14.0 \pm 0$ & $24.5 \pm 2.1$ & $29.0 \pm 1.0$ & $29.0 \pm 1.0$ & & & & & \\
\hline & & $9.5 \pm 2.1$ & $7.5 \pm 0.7$ & $20.0 \pm 1.4$ & $23.0 \pm 2.0$ & $18.5 \pm 0.5$ & & & & & \\
\hline
\end{tabular}

* The diameters of zone of inhibition were expressed in millimeter (mm) as mean \pm stand deviation (SD). 
Table.2 Antimicrobial extracellular and intracellular activity extracts obtained by using three different carbon sources and days of cultivation. Values are of 3 separate determinations, each in triplicate

\begin{tabular}{|c|c|c|c|c|c|c|c|c|c|c|c|c|}
\hline & & & \multicolumn{4}{|c|}{ Gram-negative } & \multicolumn{6}{|c|}{ Gram-positive } \\
\hline & & & \multicolumn{2}{|c|}{$\begin{array}{l}\text { E. coli } \\
25922 \\
\end{array}$} & \multicolumn{2}{|c|}{$\begin{array}{c}\text { S. enteric } \\
13076\end{array}$} & \multicolumn{2}{|c|}{$\begin{array}{c}\text { S. aureus } \\
25923\end{array}$} & \multicolumn{2}{|c|}{$\begin{array}{l}\text { B. subtilis } \\
6051\end{array}$} & \multicolumn{2}{|c|}{$\begin{array}{c}\text { B. cereus } \\
00003\end{array}$} \\
\hline & & & $\begin{array}{c}\mathrm{MIC} \\
\mathrm{mg} / \mathrm{mL}\end{array}$ & $\begin{array}{c}\mathrm{MBC} \\
\mathrm{mg} / \mathrm{mL}\end{array}$ & $\begin{array}{c}\mathrm{MIC} \\
\mathrm{mg} / \mathrm{mL}\end{array}$ & $\begin{array}{c}\mathrm{MBC} \\
\mathrm{mg} / \mathrm{mL}\end{array}$ & $\begin{array}{c}\mathrm{MIC} \\
\mathrm{mg} / \mathrm{mL}\end{array}$ & $\begin{array}{c}\mathrm{MBC} \\
\mathrm{mg} / \mathrm{mL}\end{array}$ & $\begin{array}{c}\mathrm{MIC} \\
\mathrm{mg} / \mathrm{mL}\end{array}$ & $\begin{array}{c}\mathrm{MBC} \\
\mathrm{mg} / \mathrm{mL}\end{array}$ & $\begin{array}{c}\mathrm{MIC} \\
\mathrm{mg} / \mathrm{mL}\end{array}$ & $\begin{array}{c}\mathrm{MBC} \\
\mathrm{mg} / \mathrm{mL}\end{array}$ \\
\hline \multirow{12}{*}{$\begin{array}{c}\text { Extracellular } \\
\text { Extracts }\end{array}$} & \multirow{3}{*}{2 days } & Glucose & -- & -- & 100.0 & UN & 12.5 & 25.0 & 6.25 & 25.0 & -- & -- \\
\hline & & Starch & 25.0 & UN & 100.0 & UN & 12.5 & UN & 6.25 & 25.0 & -- & -- \\
\hline & & Bagasse & -- & -- & -- & -- & -- & -- & -- & -- & -- & -- \\
\hline & \multirow{3}{*}{ 4days } & Glucose & -- & -- & -- & -- & -- & -- & -- & -- & -- & -- \\
\hline & & Starch & 12.5 & 100.0 & UN & UN & 3.12 & UN & 12.5 & UN & -- & -- \\
\hline & & Bagasse & 6.25 & 100.0 & 100.0 & UN & 6.25 & 100.0 & 0.39 & 0.78 & -- & -- \\
\hline & \multirow{3}{*}{ 6days } & Glucose & -- & -- & 100.0 & UN & 25.0 & 100.0 & 3.12 & 25.0 & -- & -- \\
\hline & & Starch & -- & -- & 100.0 & UN & 12.5 & $\mathrm{UN}$ & 3.12 & 25.0 & -- & -- \\
\hline & & Bagasse & -- & -- & 100.0 & UN & 6.25 & 25.0 & 6.25 & 25.0 & -- & -- \\
\hline & \multirow{3}{*}{ 8days } & Glucose & -- & -- & -- & -- & -- & -- & -- & -- & -- & -- \\
\hline & & Starch & -- & -- & -- & -- & 6.12 & 12.5 & 6.25 & 100.0 & -- & -- \\
\hline & & Bagasse & -- & -- & -- & -- & 1.56 & 3.25 & 3.12 & UN & -- & -- \\
\hline \multirow{12}{*}{$\begin{array}{l}\text { Intracellular } \\
\text { Extracts }\end{array}$} & \multirow{3}{*}{2 days } & Glucose & -- & -- & -- & -- & -- & -- & -- & -- & -- & -- \\
\hline & & Starch & -- & -- & -- & -- & -- & -- & -- & -- & -- & -- \\
\hline & & Bagasse & -- & -- & 100.0 & UN & 6.25 & UN & 12.5 & 25.0 & -- & -- \\
\hline & \multirow{3}{*}{ 4days } & Glucose & -- & -- & -- & -- & -- & -- & -- & -- & -- & -- \\
\hline & & Starch & -- & -- & -- & -- & -- & -- & -- & -- & -- & -- \\
\hline & & Bagasse & -- & -- & -- & -- & 6.25 & 12.5 & -- & -- & -- & -- \\
\hline & \multirow{3}{*}{ 6days } & Glucose & 6.25 & 12.5 & 100.0 & UN & 12.5 & 12.5 & 3.12 & 25.0 & 12.5 & 25.0 \\
\hline & & Starch & 6.25 & 6.25 & 50.0 & UN & 50.0 & 100.0 & 3.12 & 6.25 & 25.0 & 50.0 \\
\hline & & Bagasse & -- & -- & 100.0 & UN & 12.5 & 100.0 & 3.12 & 25.0 & -- & -- \\
\hline & \multirow{3}{*}{ 8days } & Glucose & 12.5 & 50.0 & 100.0 & UN & 3.12 & 12.5 & 3.12 & 100.0 & -- & -- \\
\hline & & Starch & -- & -- & 100.0 & UN & 3.12 & UN & 6.25 & 100.0 & -- & -- \\
\hline & & Bagasse & -- & -- & 100.0 & UN & 1.56 & 100.0 & 0.78 & 100.0 & -- & -- \\
\hline
\end{tabular}

UN: undetermined, above $100 \mathrm{mg} / \mathrm{ml}$ 
Table.3 Preliminary antifungal testing of Pleurotus pulmonarius extracts through determination of zone of inhibition $(\mathrm{mm} \pm \mathrm{SD})^{*}$ for Candida albicans ATCC 10231

\begin{tabular}{|c|c|c|c|c|c|}
\hline \multirow{2}{*}{\multicolumn{2}{|c|}{ Extracts }} & \multicolumn{2}{|c|}{ Antibiograma (IDZ mm) } & \multicolumn{2}{|c|}{ MIC (mg/ml) } \\
\hline & & Extracellular & Intracellular & Extracellular & Intracellular \\
\hline \multirow{3}{*}{ 2days } & Glucose & $15.0 \pm 0.5$ & -- & 75.0 & -- \\
\hline & Starch & $12.0 \pm 0.7$ & $14.0 \pm 0.7$ & UN & UN \\
\hline & Bagasse & -- & -- & -- & -- \\
\hline \multirow{3}{*}{ 4days } & Glucose & -- & -- & -- & -- \\
\hline & Starch & -- & -- & -- & -- \\
\hline & Bagasse & -- & -- & -- & -- \\
\hline \multirow{3}{*}{ 6days } & Glucose & -- & $17.0 \pm 0.5$ & -- & 100.0 \\
\hline & Starch & -- & $19.0 \pm 1.4$ & -- & 75.0 \\
\hline & Bagasse & -- & -- & -- & -- \\
\hline \multirow{3}{*}{ 8days } & Glucose & -- & -- & - & -- \\
\hline & Starch & -- & -- & -- & -- \\
\hline & Bagasse & -- & -- & -- & -- \\
\hline \multicolumn{2}{|c|}{$\begin{array}{l}\text { Fluconazole } \\
(0.025 \mathrm{mg} / \mathrm{ml})\end{array}$} & $21.0 \pm 0.7$ & & & 0.02 \\
\hline
\end{tabular}

* The diameters of zone of inhibition (IDZ) were expressed in millimeter (mm) as mean \pm stand deviation (SD). Each disc containing $10 \mu \mathrm{l}$ of $100 \mathrm{mg} / \mathrm{ml}$ of fungi extracts.

It is well known that Gram-negative bacteria are highly resistant to many antibiotics and our findings are consistent with this observation. When antimicrobial activity against Gram-negative bacteria was evaluated, two out of five Gram-negative bacteria tested were sensitive to the extract, and only for E. coli it was possible to determine a $\mathrm{MBC}$ value. On the other hand, all Gram-positive bacteria were sensitive to the aqueous $P$. pulmonarius extract.

In this work we found that the antimicrobial activity of the extracts of $P$. pulmonarius varied according to the source of carbon and the cultivation time. A similar dependence on the type of nitrogen source of the antimicrobial activity was reported previously for Pleurotus ostreatus cultured in submerged conditions (Vamanu, 2012).

These results suggest that the production of antimicrobial molecules by mushrooms can be regulated by the carbon source, the nitrogen source, or both.
Both high molecular weight metabolites, such as proteins and polysaccharides and low molecular weight compounds, such as the sesquiterpenes and other terpenes, steroids, anthraquinones, benzoic acid derivates, and quinolones, can be responsible by antimicrobial activity of mushrooms and could be used for the development of new antimicrobial drugs (Alves et al., 2012). In fact, numerous bioactive compounds with antimicrobial activity have been identified from the fruiting bodies, cultured mycelia and culture filtrates of Pleurotus ssp. and include polysaccharides (Llauradó et al., 2015), fatty acid esters (Suseem and Saral, 2013) and an organic acid identified as 3-(2aminophenylthio)-3-hydroxypropanoic (Younis et al., 2015).

In conclusion, aqueous mycelial extracts of $P$. pulmonarius seems to be a promising natural source of antimicrobial agents. Experiments must be conducted to identify the molecules responsible for this activity. 


\section{Acknowledgments}

The authors thank $\mathrm{CNPq}$ (Conselho Nacional de Desenvolvimento Científico e Tecnológico), Fundação Araucária and Universidade Estadual for financial support.

\section{References}

Adebayo, E.A., Oleke, J.K., Ayandele, A.A., and Adegunlola, C.O. 2012. Phytochemical, antioxidant and antimicrobial assay of mushroom metabolite from Pleurotus pulmonarius- LAU 09 (JF736658), $J$. Microbiol. Biotechnol., 2(2): 366-374.

Alves, M.J., Ferreira, I.C.F.R., Dias, J., Teixeira, V., Martins, A., and Pintado, M. 2012. A Review on antimicrobial activity of mushroom (Basidiomycetes) extracts and isolated compounds. Planta Med., 78, 17071718.

Barakat, O.S., and Sadik, M.W. 2014. Mycelial growth and bioactive substance production of Pleurotus ostreatus in submerged culture. Int. J. Curr. Microbiol. App. Sci., 3(4):10731085.

Corrêa, R.C.G., Brugnari, R., Bracht, A., Peralta, R.M., and Ferreira, I.C.F.R. 2016. Biotechnological, nutritional and therapeutic uses of Pleurotus spp. (Oyster mushrooms) related with its chemical composition: A review on the past decade findings. Trends Food Sci. Technol., 50, 103-117.

Corrêa, R.C.G., Souza, A.H.P., Calhelha, R.C., Barros, L., Glamoclija, J., Sokovic, M., Peralta, R.M., Bracht, A., and Ferreira, I.C.F.R. 2015. Bioactive formulations prepared from fruiting bodies and submerged culture mycelia of Brazilian edible mushroom Pleurotus ostreatoroseus Singer. Food Funct., 6, 2155-2164.
Dharmaraj, K., Kuberan, T., and Mahalakshmi, R. 2014. Comparison of nutrient contents and antimicrobial properties of Pleurotus djamor, Agaricus bisporus and Ganoderma tsugae. Int. J. Cur. Microbiol. App. Sci., 3, 518-526.

Elisashvili, V. 2012. Submerged cultivation of medicinal mushrooms: bioprocesses and products (Review). Int. J. Med. Mushrooms, 14(3): 211239.

Llauradó, G., Morris, H.J., Ferrera, L., Camacho, M., Castán, L., Lebeque, Y.,Beltrán, Y., Cos, P., andBermúdez, R.C. 2015. In-vitro antimicrobial activity and complemente/macrophage stimulating effects of a hot-water extract from mycelium of the oyster mushrooms Pleurotus sp. Innov. Food Sci. Emerg. Technol., 30, 177-183.

NCCLS (Clinical and Laboratory Standards Institute). 2008. Method for antifungal disk diffusion susceptibility testing of yeasts: approved standard M44-A2. Wayne, Pennsylvania.

NCCLS (Clinical and Laboratory Standards Institute) 2003a. Performance standards for antimicrobial disk susceptibility tests: approved standard. NCCLS document M2-A8, Wayne, Pennsylvania.

NCCLS (Clinical and Laboratory Standards Institute) 2003b. Methods for dilution antimicrobial susceptibility tests for bacterial that grow aerobically: approved standard. NCCLS document M7-A6, Wayne, Pennsylvania.

Ragunathan, R., and Swaminathan, K. 2003. Nutritional status of Pleurotus spp. grown on various agro-wastes. Food Chem., 80, 371-375.

Sala U.G.M., Sarwar H.M., Monirul, I.M., Asaduzzaman M., Jahan bulbul I., and Ruhul A.M. 2015. Evaluation of antimicrobial, antioxidant and 
cytotoxic property of Pleurotus ostreatus mushroom. Int. Res. J. Biol. Sci., 4(1): 29-33.

Santurio, J.M., Santurio, D.F., Pozzatti, P., Moraes, C., Franchin, P.R., and Alves, S.H. 2007. Atividade antimicrobiana dos óleos essenciais de orégano, tomilho e canela frente asorovares de Salmonella enterica de origem avícola, Ciênc. Rural, 37(3): 803-808.

Schillaci, D., Arizza, V., Gargano, M.L., andVenturella, G. 2013. Antibacterial activity of Mediterranean oyster mushrooms, species of genus Pleurotus (Higher Basidiomycetes), Int. J. Med. Mushrooms, 15(6): 591594.

Susueem, S.R., and Saral, A.M. 2013. Analysis on essential fatty acid esters of mushroom Pleurotus eous and its antibacterial activity. Asian $J$. Pharm.Clin. Res., 6, 188-191.

Vamanu, E. 2012. In vitro antimicrobial and antioxidant activities of ethanolic extract of lyophilized mycelium of Pleurotus ostreatus PQMZ91109. Mol., 17, 3653-3671.

Vogel, H.J. 1956. A convenient growth medium for Neurospora crassa. Microbial. Gen. Bull., 13, 42-43.

World Health Organization. 2012. The evolving threat of antimicrobial resistance - options for action, WHO Press, Geneva, Switzerland. Pp. 2- 6.

Younis, A.M., Wu, F-S., and Shikh, H.H. 2015. Antimicrobial activity of extracts of the oyster culinary medicinal mushroom Pleurotus ostreatus (Higher Basidiomycetes).

\section{How to cite this article:}

Bruna Polacchine da Silva, Josielle Abrahão and Rosane Marina Peralta. 2016. Effects of Carbon Sources and Time of Cultivation on the Antimicrobial Activities of Intra and Extracellular Extracts of Pleurotus Pulmonarius Cultured in Submerged Conditions. Int.J.Curr.Microbiol.App.Sci. 5(11): 97-105. doi: http://dx.doi.org/10.20546/ijcmas.2016.511.011 